\title{
Complete Blood Count and Cinnamic acid activity against Cytoxan in albino mice.
}

\author{
Nibal Kh. Mousa* \\ Azher S. Abd Al-Karime
}

\author{
Shahad Sh. Sabbar* \\ Ishrak Ab. Ahmed **
}

Received 20, December, 2012

Accepted 5, February, 2014

\begin{abstract}
:
The aim of study to evaluated cinnamic acid and its activity on complete blood count(RBC,WBC,HG,HCV,MCH,MCHC and Plat.)and removed the cytoxan damage which caused bone marrow failure and leukemia and other that due to linked the cytoxan in 7- nitrogen of guanine based of DNA that lead to dead cells. Two concentration from pure cinnamic acid $(5.6,2.8 \mathrm{mg} /$ mice weight) in first step to choice the perfect concentration in comparison with each negative control, positive control of cytoxan and the comparison group represent vitamin $\mathrm{C}$. The second step to understand cinnamic acid mechanism activity towards cytoxan by used pre- cytoxan and post - cytoxan in interaction with perfect concentration of cinnamic acid dose ( $2.8 \mathrm{mg} /$ mice weight). The analysis showed that cinnamic acid removed each kinds of anemia ,leukemia, bone marrow failure, hypoxia, cancer chemotherapy, hemolytic anemia and hormone erythropoietin from kidney failure in post-cytoxan than precytoxan perfectly ,therefore, cinnamic acid has cure ability and removed cytoxan damage and can give to patient whom used cytoxan in transplanting body part surgeries to a void refused the part for 6 days after transplanting surgeries.
\end{abstract}

Key words: Cinnamic acid, Cytoxan, Complete Blood Count, Mice.

\section{Introduction}

In the last decades, the development industry and growing human action in discovery many chemical components that use in difference sides, some of them, pesticides industry, drugs and nutrition industry, which increasing the environmental pollution and reflected on the health of human body [1].These compounds have the ability to cause damage in different tissues and systems of human body, whether the expose directly or indirect albeit little concentrations because most of them can accumulation in cells and tissue, then conversion to derivatives rich in electrons [2].The frequently cell exposed execute to making changes in DNA that endly caused cancer. The statistics assure that near $85 \%$ from mutation components are cancered components [3].

The effect of Cytoxan toxicity on liver is due to activation of aldophosphamide, is alkyating antineoplastic and immunosuppressive agent that must be activated in the liver, it can cause sterility, birth defects, mutation and cancer. It's one of the many imported components the searchers whipped before the last half century, found assignment mechanisms and basic to damage tissue contrast to lots mechanisms from chemical components, some of them are metabolisms action, mechanism free radical and per oxidation lipids operation, equilibrate trouble of calcium rates in tissues and the indicators about damages [4].

*Environmental-Water Research and Technology Directorate, Ministry of Science and Technology.

**The National Center for Drug Control and Research, Ministry of Health. 
Plants have the role in inhibition cancered components and protective effects. The primary studies show that the cancer less rate in societies that vegetarianism habitat in compare with societies least used plants in their daily food [5]. The natural vegetarianism components, nutrition and nonnutrition due to their important role in keeper the human health and improvement his life.

The bioaviabilities of plant polyphenol and their ability to inhibit and prevent tumor after entering blood circulation and absorbing by bowel belong to their effection on protein or control factors and the role in repairing cells [6], in addition to motivate immunology system, increasing natural killer cells (NK) and effect on the enzymes which responsible of process and complete the cell cycle by hyperexpression arrangement [7].

A Complete Blood Count (CBC) gives important information about kinds and numbers of cells in the blood, especially Red Blood Cells (RBCs), White Blood Cells (WBCs) and platelets. A CBC(Complete Blood Count) helps in diagnosing conditions, such as anemia, infection, and many other disorders. To quantify the toxicity of CYP(cytoxan), the next important step is to assess the various hematological parameters such as Hematocrit (HCT), Hemoglobin(HB), Red Blood Cells (RBCs), White Blood Cells (WBCs) and Platelets (PLTs) counts[8].

In the last years, the consumption of cinnamon increasing widely in many countries, because of the ability to prevent some kinds of cancer due to their components and its effect on mutation and cancer by interacting in metabolism reactions and biopathways of these components in body[9]. The searcher interesting increased in finding methods express the components characters of
Cinnamon such as cinnamic acid and invention of the activity to know if they are oxidant or antioxidant, cancered or protective. Many of organizations and science corporations recommended to apply and use the biosystem to detect the toxicity of manufacture components or natural whether are invitro or invivo, some of them the mammalian systems that use the animals of laboratory mice with all different organisms, blood cells and bone marrow in additional the sexual cells like spermatic .

The aim of study $t$ evaluated cinnamic acid in removing the cytoxan effect that reflect on complet blood count and documented the ability of cinnamic acid in removed bone marrow failure and leukemia due to cytoxan which had no reported before.

\section{Material and Methods:}

Material:Phosphate Buffer Solution(PBS) (9).Colchicine Solution : Colchicine1mg (one tablet)and sterile distilled water $1 \mathrm{ml}$.The solution was used immediately after preparing 2.5 to 3 hours[11].

Doses: Two doses from the pure cinnamic acid (Riedel-de Haën company)which are $(5.6,2.8) \mathrm{mg} /$ mice weight and vitamin $\mathrm{C}(180 \mathrm{mg} / \mathrm{kg}$ )[12](as comparative groups and cytoxan compound in $(50 \mathrm{mg} / \mathrm{kg})$ [13] as a positive control and the PBS as a negative control[14].

The experiment: Two concentration from pure cinnamic acid $(5.6,2.8) \mathrm{mg} /$ $\mathrm{Kg}$, the concentration a count depended on the mouse weight .The experiment contains 40 mice divided in to 5 groups of 8 mice each (16 mice gulped with the two cinnamic acid concentration $(5.6,2.8) \mathrm{mg} /$ mice weight, 8 mice gulped with PBS and depended as a negative control ,8 mice injected with cytoxan compound and depended as a positive control ,8 mice gulped with 
vitamin $\mathrm{C}$ and depended as a comparative groups and from the two control) and the comparative groups can gain primary idea about the suitable concentration to cinnamic acid ,then study the before- cytoxan and post cytoxan to understand cinnamic acid mechanisms .

Collection of Blood and Serum :The blood was collected from the heart of mice(Mus musculus) and collected for experiment using Heparin(10 units $/ \mathrm{ml}$ ) as the anticoagulant from all animals on the seventh day after experiment[15].

\section{Hematological analysis: An} hematological autoanalyzer (Orphee Mythic 22 Hematological Analyzer; Diamond Diagnostic; USA) was used to determine different hematological parameters, such as Red Blood Cells (RBC), WhiteBlood Cells (WBCs), Hemoglobin (HB), Hematocrit (HCT), Mean

Corpuscular Volume (MCV), Mean Corpuscular Hemoglobin (MCH), Mean Corpuscular Hemoglobin Concentration (MCHC), Red blood cell Distribution Width (RDW), Platelet Distribution Width (PDW)\%, Plateletcrit (PCT)\% and Platelets (PLTs)[16].

Statistical analysis :The statistical analysis is done to get the means $\pm \mathrm{SE}$ and test the different significant among the means by using test [17] then differences among the means in interaction experiments were compared between the Vitamin $\mathrm{C}$, cinnamic extract and the cytoxan by using $\mathrm{T}$ - test [18].

\section{Results and Discussion:}

Cytoxan results and pure cinnamic acid treat invivo (7 days).

The effect of the perfect concentrated of cinnamic acid extract (2.8mg / mice weight) for 7 days treatment in mice were showed lack of influence, other denoted like changes in color and thickness of mice hair, eyes shape, change in weight, change in liver function enzymes and the antioxidant enzyme, while concentration ( $5.6 \mathrm{mg} /$ mice weight) showed lowing in weight and changes in color of mice hair which became light yellow, lowing in thickness and losing hair in some parts of the body, beside that changes in the eyes shape and lose there bright, other side, showed increasing in the LFTs and the antioxidant enzymes[19]when compared with the negative, positive treated and Vit.C because high dose of vitamins and minerals can be toxic [20].

The concentration $(2.8 \mathrm{mg} / \mathrm{mice}$ weight) of cinnamic acid extract showed excellent results in increasing weight tab(1), active in moving, increasing the ability to eat more, increasing in mice hair thickness to be more white than the normal and the eyes were bright with no changes in shape. In the other side the LFTs and the antioxidant were a good results (when compared with the negative, positive treated and Vit. C). Cyclophosphamide was injected in intraperitonial member because gulping caused losing between (3-12) hours [21].

Cytoxan was caused inactive in moving of mice, losing the hair in the back, legs, shoulders and lowing in LFTs and the antioxidant enzymes[14], because cyclophosphamide was a chemotherapy drug, work by slowing or stopping cell growth when the alkyl group from the cyclophosphamide attaches guanine base in the 7 nitrogen at one of the imidazole ring and stopping the cell divided [21]. Cytochrome P-450 was agroup of enzymes in endoplasmic reticulum known as the most important family of metabolizing enzymes in liver and the 
terminal electron transport chain of oxidase [22].

The main effect of cytoxan by metabolizing the phosphoramide mustard in the cell which have low of aldehyde dehydrogen (ALDH). Phosphoramide mustard forms DNA cross links between inter strand cross linkages within intra strand cross linkages at guanine N-7 position with irreversible and leads to dead the cell. Dead cell by cell caused hyper acute liver failure [23].

The lymphocytes (WBC) represent the first line against the different infections in body (24).Cytoxan(medicine that can decrease the immune response)[21] has been showed lower than normal white blood cell counts which called leucopenia which may be due to autoimmune disease, bone marrow failure(4)tumor, fibrosis and disease of liver [14,19]. when compared with negative control (PBS) and vitamin C., while the cinnamic acid (56mg $/ \mathrm{kg}$ )showed increased than normal of numbers of WBCs which called leukocytosis when compared among PBS vitamin $\mathrm{C}$ and cytoxan treatment ,results from leukemia and tissue damage[25].

Red Blood Count or hematacriti showed decreased in both cytoxan and cinnamic acid (5.6 mg/ mice weight) when compared with PBS and vitamin C..The reduce in RBCs count means increased destruction of red blood cells or layses of red blood cells .Lack of iron, vitamin B12, folic acid in diet as well as certain chronic diseases [19].Lower the number of red blood cells produced by bone marrow failure ,chronic kidney disease ,hemolysis , leukemia ,long term infections (hepatitis)and other blood cancers due to tumor or fibrosis [26].cytoxan caused red blood cells to break down earlier than normal which called immune hemolytic anemia secondary to drugs. In the same time cinnamic acid (2.8 $\mathrm{mg} /$ mice weight) showed increased with normal when compared with vitamin $C$ and BPS and cytoxan.

Hematocrit (HCT) is a blood measures the percentage of whole blood volume that is made up of red blood cells.this measured depend on the number of red blood cells and the size of RBCs.Cytoxan fig (1) showed lower than normal in hematocrite may due to anemia ,bleeding ,overhydration, nutrition deficiencies of iron ,floate, vitamin B12, B6, malnutrition ,destruction of red blood cells [27]in compared with PBS and vitamin C.Cinnamic acid $(5.6 \mathrm{mg} / \mathrm{mice}$ weight)showed high hematocrite may be due to congenital heart diseases, corpulmonale, dehydration, erthyocytosis, low blood oxygen levels (hypixia) [27], while cinnamic acid showed normal increased incompared with PBS and vitamin.

Hemoglobin is a protein in red blood cells that carried oxygen [27].I $n$ fig (1)cytoxan showed lower than normal may be due to various types of anemia such as chronic disease and leukemia [28], while cinnamic acid (5.6 mg / mice weight) showed higher than normal may be due to heart diseases ,erthyocytosis and hypoxia but cinnamic acid (2.8 mg / mice weight) showed increased with normal when compared with each PBS and vitamin C.

Red Blood Cells (RBCs) induces are part of the complete blood count (CBC) test. They are used to help diagnose the cause of anemia a condition in which there are too few red blood cells. RBCs include: Average red blood cell size (MCV) ,hemoglobin amount red blood cell $(\mathrm{MCH})$ and $\mathrm{MCHC}$ referred to the amount of hemoglobin relation to the size of the cell (hemoglobin concentration)per red blood cell. IN fig (1) cytoxan showed decreased in MCV 
which means microcytic anemia [27, 28] and increased in $\mathrm{MCH}$ mean normochronic anemia and decreased in MCHC mean different types of anemia when each one compared with PBS and vitamin C. Microcytic anemia / normochronic anemia results from adeficiency of the hormone erthyropoietin from kidney failure [28]while cinnamic acid (2.8 mg / mice weight ) showed normal levels in $\mathrm{MCH}$ ,MCV and MCHC when compared with BPS, vitamin $C$ and cytoxan.

Platelets count help the blood clot. They are small than red and white blood cells. In fig (1) cytoxan showed lower than normal levels of platelets numbers when has been compared with PBS and vitamin C.which due to cancer chemotherapy [21],hemolytic anemia hyperspleism,leukemia,and heart valve [27]while cinnamic acid $(2.8 \mathrm{mg} /$ mice weight )showed increased with normal numbers when has been compared with PBS, vitamin $\mathrm{C}$ and cytoxan treatment.

Interaction between Cytoxan and Perfect concentration of cinnamic acid ( $2.8 \mathrm{mg} /$ mice weight).

The interaction among cytoxan and PBS, vitamin $\mathrm{C}$ and perfect concentration of cinnamic acid dose $(2.8 \mathrm{mg} /$ mice weight)in postcytoxan showed in fig(2)the best results in comparison with pre-cytoxan treatment .Cinnamic acid dose $(2.8 \mathrm{mg}$ /mice weight) showed high reaction in remove cytoxan effects and increased each of WBC,RBC,MCH,MCHC,MCV,HCT, HG and platelets count, mechanisms of cinnamic acid to repair removed were:

1. Avoid and prevent hydroxyl radical as a product of hydrogen peroxide and gave the first spark for start the chemical interaction such as lipid peroxidation [29].

2. Avoid or prevent or repair oxidation of DNA and protein, which depend on the hydroxyl groups of cinnamic acid [30,31].

3. Cinnamic acid was suppressed hepatic fibrosis and protected liver against damage [32].

4. Cinnamic acid have antihyperlipidemic action [33].

5. Release of inflammatory mediators such as cytokines, histamine, prostaglandins and leukotrenes to protect hepatocyte [33].

6. The liver cytochrome p-450 system converts cyclophosphamide to 4hydroxycyclophosphamide, which is a equilibrium with aldophosphamide. phosphoramide mustard and acrolien were yielded from cleavage aldophosphamide. These two compounds are highly cytotoxic .Cyclophosphamide is uncommon hepatic toxin and its effect was due to an idiosyncratic reaction [34].

7. Cinnamic acid has kept liver enzyme in normal level such as ALP when increased reflected on bone marrow ,AST when increased more than normal level reflected on red cell and cardiac when comparesioin with vitamine C.[19]

\section{Conclusion:}

1.Cinnamic acid has no side effect in dose $2.8 \mathrm{mg} /$ mice weight.

2.Leukopenia,bone marrow failure and fibrosis which reflected from decreased WBC due to cytoxan removed by pure cinnamic acid in post-cytoxan perfectly.

3.All kinds of anemia which reflected from hemoglobin (HG)analysis removed when used cinnamic acid dose $(2.8 \mathrm{mg} /$ mice weight $)$ perfectly in post-cytoxan treatment.

4. Anemia bleeding ,heart disease and low blood oxygen levels (hypoxia) which reflect from hematocrit (HCT) removed due to cinnamic acid dose (2.8 $\mathrm{mg} /$ mice weight) perfectly in post-cytoxan treatment. 
5.The ratio between $\mathrm{MCHC} \mathrm{MCH}$ showed microcytic anemia normochronic anemia due to deficiency of hormone erythropoietin from kidney failure which reflected from cytoxan treatment in each perfect concentration pre-cytoxan and postcytoxan and removed perfectly in post- cytoxan due to cinnamic acid dose $(2.8$ $\mathrm{mg} /$ mice weight ).

6.The ratio of ratio platelets count (RWD/CV,RDW/SD)showed increased in normal could removed (cancer chemotherapy, hemolytic anemia and leukemia )cytoxan effects perfectly by cinnamic acid dose $(2.8 \mathrm{mg} /$ mice weight) in post-cytoxan treatment.

Table 1: Different in mice weight means treated for 7 days.

\begin{tabular}{|c|c|c|c|c|c|}
\hline $\mathrm{C}_{\text {Test }}^{\text {Treat }}$ & $\begin{array}{l}\text { Negative } \\
\text { group } \\
\text { (PBS) }\end{array}$ & $\begin{array}{l}\text { Comparative } \\
\text { group Vit.C } \\
(180 \mathrm{mg} / \mathrm{Kg}) \\
\end{array}$ & $\begin{array}{c}\text { Positive group } \\
\text { Cyclophosphamide } \\
(50 \mathrm{mg} / \mathrm{Kg})\end{array}$ & $\begin{array}{c}\text { Cinnamic acid } \\
(5.6 \mathrm{mg} / \mathrm{mice})\end{array}$ & $\begin{array}{l}\text { Cinnamic acid } \\
(2.8 \mathrm{mg} / \mathrm{mice})\end{array}$ \\
\hline \multicolumn{6}{|c|}{ Mean \pm SE (gram) } \\
\hline $\begin{array}{c}\text { The mouse weight } \\
\text { before treating }\end{array}$ & $25.07 \pm 1.17$ & $26.7 \pm 0.20$ & $29.65 \pm 0.30$ & $28.55 \pm 0.35$ & $26.7 \pm 0.24$ \\
\hline $\begin{array}{c}\text { The mouse weight } \\
\text { after treating }\end{array}$ & $29.75 \pm 0.35$ & $26.99 \pm 0.49$ & $21.15 \pm 2.49$ & $29.45 \pm 0.75$ & $32.26 \pm 0.44$ \\
\hline Weight deferent & $4.68 \pm 0.002$ & $0.29 \pm 0.03$ & $-8.5 \pm 0.32$ & $0.9 \pm 0.52$ & $5.56 \pm 0.33$ \\
\hline
\end{tabular}

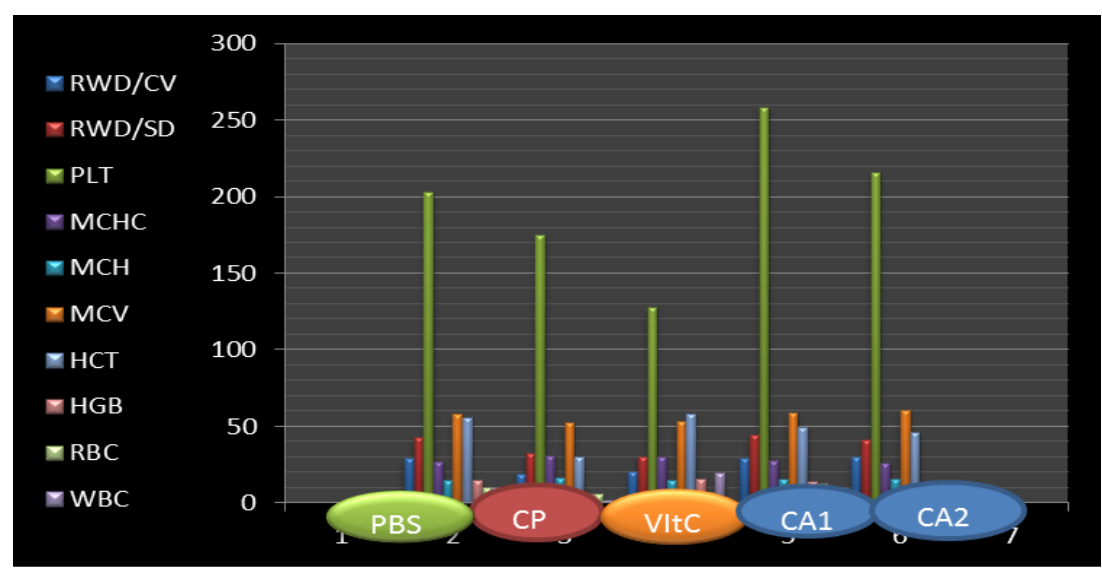

Fig (1)Complet blood count and perfect concentration of cinnamic acid.

PBS:phosphate buffer solution,CP:cytoxan,CA:CA1:cinnamic acid dose (5.6 mg /mice),CA2:cinnamic acid dose(2.8mg / mice).

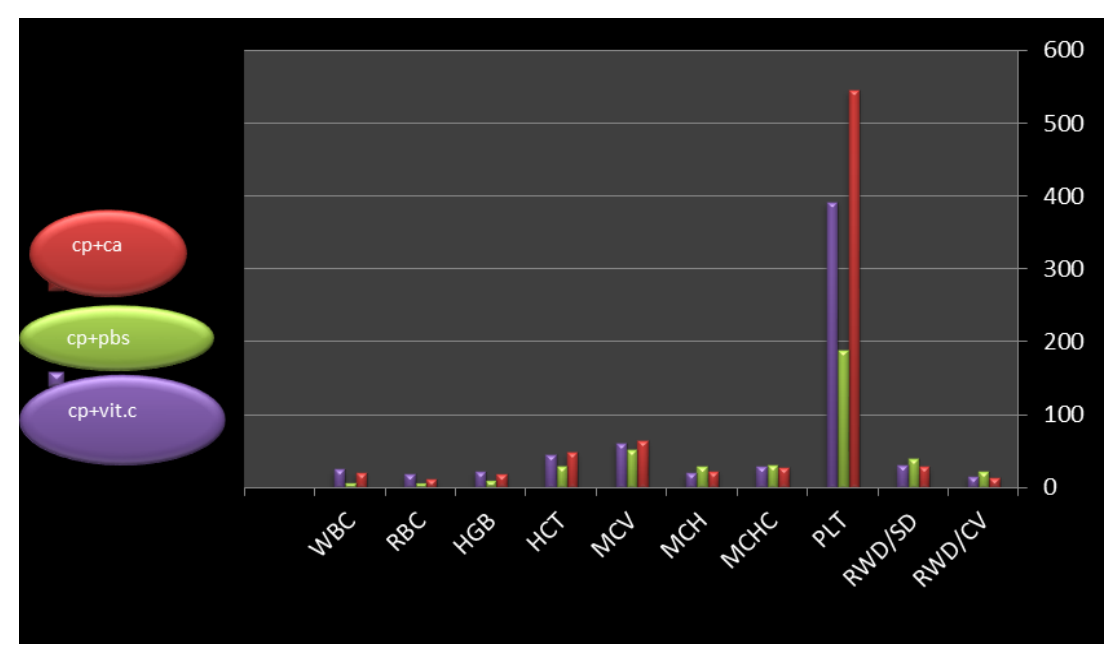

Fig (2) complet blood cell and post-cytoxan treatment.

PBS: phosphate buffer solution,CP:cytoxan,CA:CA1:cinnamic acid dose $(5.6 \mathrm{mg}$ /mice),CA2:cinnamic acid dose(2.8mg / mice). 


\section{References:}

1. FAO. (2004). Biotechnology applications in food processing .Electronic forum on Biotechnology in Food and Agriculture. Conference11. United Nation.

2. Kohlmeier, L. ; Simonsen, N. and Mottus, K. (1995). Environmental Health Issues. Environ. Health Perspoct, $103: 1-11$.

3. Kier, L. D. ; Brusick, D. J. ; Auletta, A. E. ; Halle, E. S. ; Brown, M. M. and Simmon, V. F. (1986). The Salmonella typhimurium/ mammalian microsomal assay : A report of the U.S. Environmental Protection Agency Gen-Tox Program. Mut. Res. $168: 240-269$.

4. Klein, T. E. ; Chang, J.T. ; Cho, M. K. ; Easton, K. L. ; Fergerson, R. ; Hewett, M. ; Lin, Z. ; Liu, Y. ; Liu, S. ; Oliver, D. E. ; Rubin, D. L. ; Shafa, F. ; Stuart, J. M. and Altman, R. B. (2001) "Integrating Genotype and Phenotype Information: An Overview of the Pharm GKB Project" , The Pharmacogenomics Journal 1, 167-170.

5. Kotake-Nara, E. ; Kushiro, M. ; Zhang, H. ; Sugawara, T. ; Miyashita, K. and Nagao, A. (2001). Carotenoids affect proliferation of human prostate cancer cells. J. Nutr. 131: 33033306.

6. Tsuda, H. ; Ohshima, Y. ; Nomoto, H. ; Fujita, K. ; Matsuda, E. ; ligo, M. ; Takasuka, N. and Moore, M. A. (2004). Cancer prevention by natural compounds. Drug Metab. Pharmacokinet, 19 : 245-263.

7. Roomi, M.W. ; Ivanov, V. ; Kalinovsky, T. ; Niedzwiecki, A. and Rath, M. (2005). In vitro and in vivo antitumorigenic activity of a mixture of lysine, proline, ascorbic acid, and green tea extract on human breast cancer lines MDA-MB-231 and MCF-7. Med. Oncol. 22 : 129-138.

8. Powers A, Silberstein LE. Autoimmune hemolytic anemias. In: Hoffman R, Benz EJ Jr., Shattil SJ, et al, eds. Hoffman Hematology: Basic Principles and Practice. 5th ed. Philadelphia, Pa: Churchill Livingstone Elsevier;2008:chap 47.

9. Al-Zubaidi, L. Ah. (2005). Inhibition activity of bark cinnamon extracts against some microorganisms to be used in ground meat preservation, MS.C, Genetic Engineering and Biotechnology Institute for Postgraduate Studies, Baghdad, Iraq.

10. WHO. (1993). Research Guidelines for Evaluating the Safety and Efficacy of Herbal Medicines. Regional Office for the Western Pacific, Manila.

11. Jwad, Bassim M. (2010). Toxicopathological and Mutagenic effects of fluoride given in drinking water to male mice University of Baghdad College of Veterinary Medicine.

12. Al-Rubaie, Elham, Ab., Khalaf. (2005).The Antimutagenic Effects of Eruca sativa and Daucus carota in Bacteria and Mammalian system.M.Sc. Genetic Engineering and Biotechnology Institute for Post Graduate Studies.

13. McDonald ,G. B.; Slattery, J. T.; Bouvier M. E. (2003). Cyclophosphamide metabolism, liver toxicity, and mortality following hematopoietic stem cell transplantation, Blood, vol. 101, no. 5, pp. 2043-2048.

14. Mousa,Nibal,Kh.;Labeeb,Ah.,AlZubaidi,Ishrak,Ab,Ahmed.(2011) .Evaluation Toxic oxidant activity 
for pure cinnamic acid in albino mice,Journal of Madenat Alelem College ,3(2)34-4.

15. Al-Zubaidi, L. Ah. (2009). Antioxidantal, antimutagenic of pure curcumin against the mutant carbon tetrachloride and its role in mice embryogenesis, Ph.D., Genetic Engineering and Biotechnology Institute for Postgraduate Studies, Baghdad, Iraq.

16. Marks PW, Glader B. Approach to Anemia in the Adult and Child. In: Hoffman R, Benz EJ, Shattil SS,( 2008).Hematology: Basic Principles and Practice. 5th ed. Philadelphia, Pa: Elsevier Churchill Livingstone:chap 34.

17. Duncan, D. B. (1955). Multiple ranges and multiple $F$ - test biometrics 11: 1-42.

18. Steel, R. G. D. and Torrie, J. H. (1980). Principle and Procedure of Statistics. ( $2^{\text {nd }}$ ed). McGraw Hill: New York

19. Mousa,Nibal,Kh.,;Labeeb,Ah.,AlZubaidi,Iman,I.,Qatia,Ishrak,Ab,A hmed.(2011)

Biochemical,Hepatoprotective

Effects of pure cinnamic acid Against Cyclophosphamide in white mice,Journal of Madenat Alelem College ,3(2)45-65.

20. Moss Ralph, W. (2000).Antioxidants Against Cancer .Brookly .NY;Equinox press ,Inc.

21. Takimoto, CH. ; Calvo, E. ; Pazdur, R. ; Wagman , LD. ; Camphausen, KA. and Hoskins, WJ. (2008). "Principles of Oncologic Pharmacotherapy" in (Eds) Cancer Management: A Multidisciplinary Approach. 11 ed.

22. Brock,

$\mathrm{N}$.

(1989). "Oxazaphosphorine cytostatics : past-present-future. Seventh Cain
Memorial Award lecture". Cancer Res. Vol. 49, No. 1. Page : 1-7.

23. Bolaños-Meade J, Fuchs EJ, Luznik L, Lanzkron SM, Gamper CJ, Jones RJ, Brodsky RA.(2012). HLA-haploidentical bone marrow transplantation with posttransplant cyclophosphamide expands the donor pool for patients with sickle cell disease.

24. Abdelhalim1,M. A. and Moussa ,Sh. A. (2012). The Dimensional Hematological Alterations Induced in Blood of Rats In vivo by Intraperitoneal Administration of Gold Nanoparticles, Nanomed Nanotechol3:4.

25. Goldman L, Schafer AI, (2011). Cecil Medicine. 24th ed. Philadelphia, PA: Saunders Elsevier;chap 161.

26. . Hoffbrand AV and Pettit JE. (2000).Color Atlas of Clinical Hematology. London, England.

27. Schmaier AH. Laboratory evaluation of hemostatic and thrombotic disorders. In: Hoffman R, Benz EJ Jr, Shattil SJ.(2008) Hoffman Hematology: Basic Principles and Practice. 5th ed. Philadelphia, Pa: Churchill Livingstone Elsevier;chap 122.

28. Novak RW.(1984) Lack of validity of standard corrections for white blood cell counts of bloodcontaminated cerebrospinal fluid in infants. $A m \quad J$ Clin Pathol;82(1):95-97.

29. Lertlakana, B. ; Somdet, S. ; Duangta, K. ; TTawat, T. ; Hathairat, Th. and Tanin, B. (2011). Hepatoprotective effects olychee (Litchi Chinensis Sonn) : A combination of Antioxidant and anti-apoptotic activities .Journal Ethnopharmacol, Thailand. 8 :4954.

30. Valko, M. ; Izakovic, M. ; Mazur, M. ; Rhodes, C. and Telser, J. (2004). Role of oxygen radicals in 
DNA damage and cancer incidence. Mol. Cell Biochem. 266 : 37-56.

31. Nakabeppu, Y.; Sakumi, K.; Sakamoto, K. ; Tsuchimoto, D. ; Tsuzuki, T. and Nakatsu, Y. (2006). Mutagenesis and carcinogenesis caused by the oxidation of nucleic acids. Biol. Chem. 387: 373-379.

32. Yamamoto,J.;Yamada,K.;Naemur a,A.;Yamashita,T.and

Arai,R.(2005).Testing various herbs for antithrobotic effect.Nutrition, 21:580-587.

33. Suanarunsawat,T.;Wacharaporn,D. ;Songsak,T.and

Rattanamahaphoom.J. (2009). Antilipidemic action of essential oil extracted from Ocimum sanctum K.Leaves in rates fed with high cholesterol diet .J.Appl.Bioomed., 7:45-53.

34. Aubrey,DA.(1970).Massive hepatic necrosis after cyclophosphamide, Br. Med. J., 3:588.

\section{تعداد الدم الكامل وفعالية حامض السيناميك تجاه السايتوكسان في الفئران المختبرية المينامية

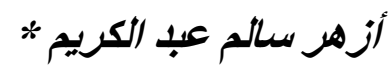

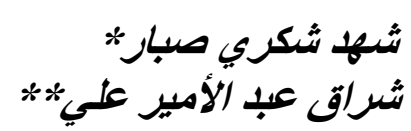

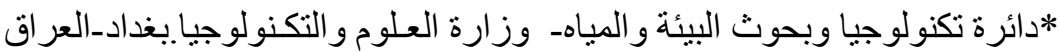

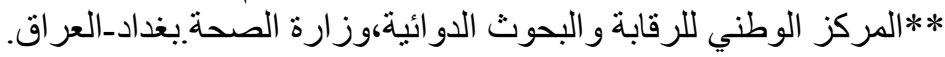

اجريت الدراسة لاجل تقييم ومعرفة مدى فعالية حامض السيناميك على نشاط تعداد الدم الكامل

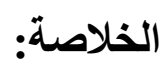

RBC,WBC,HG,HCV,MCH,MCHC and Plat)

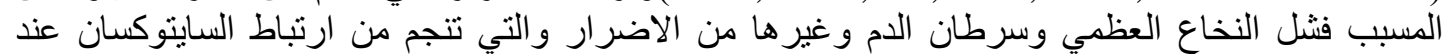

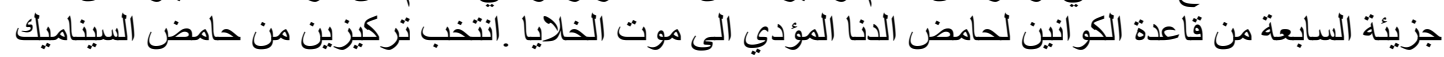

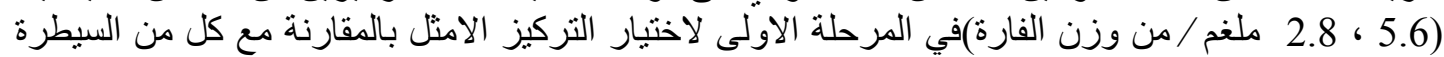

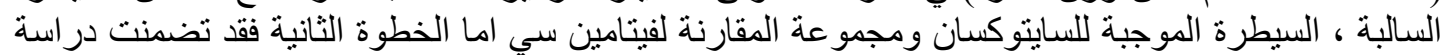

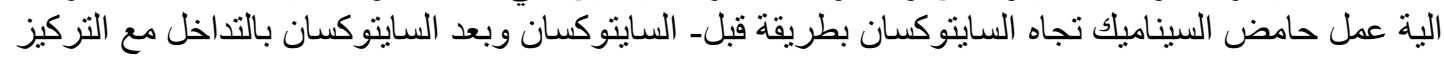

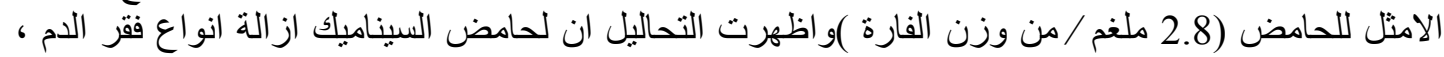

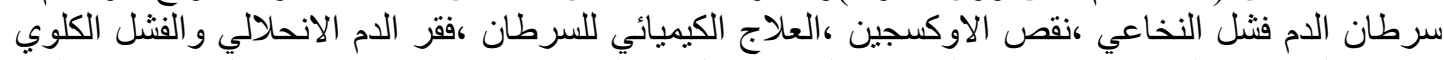

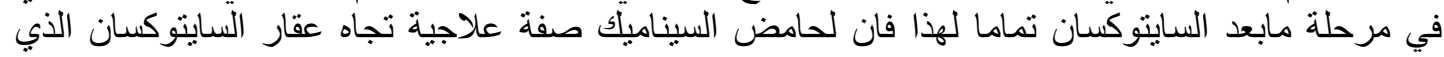

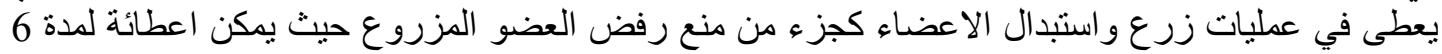
ايام بعد أجر اء العملية واز الة ضرات الترال الاعار . 